\title{
Comparison of Virtual Analysis of Diosgenin and Tigogenin Which Has Potential Down-Regulating Androgen Signaling
}

\author{
Erinda Hidayatus Safitri ${ }^{1}$, Januar F. R. ${ }^{1}$, Shifaaun Najihah ${ }^{1 *}$ \\ ${ }^{1}$ Department of Biology, Faculty of Mathematics and Natural Sciences, Brawijaya University \\ J1. Veteran, Malang 65145, East Java, Indonesia 65145
}

Submission: August 2019; Revised: September 2019: Accepted: October 2019

*Corresponding author: Shifaaun Najihah; e-mail: shifaunnajihah@gmail.com

\begin{abstract}
Costus speciosus contain several compounds that are important for fitocontraception, such as diosgenin and tigogenin. This study focused on analyzing the potential of diosgenin and tigogenin to down-regulate the androgen signaling with in silico. The androgen receptor $(A R)$ was downloaded from the protein database with ID number $1 A 28$. The diosgenin (CID: 119245) and tigogenin (CID: 99516) were obtained from Pubchem. Optimizing the energy of ligands was established using Pyrx. AR was docked with diosgenin and tigogenin using Hex 8.0.0. The interactions were visualized by Discovery Studio Client 3.5. The results showed that the interaction in the complex of Androgen Receptor with Diosgenin (ARD) and Androgen Receptor with Tigogenin (ART) occured in the ligand binding domain (LBD) area. ART had two hydrogen bonds (PRO817 and VAL818), while ARD had only one hydrogen bond (GLN798). There were 11 Van Der Walls bonds in ARD and 5 Van Der Walls bonds in ART. ARD still had unfavourable bump. ART had more hydrophobic bonds and alkyl groups than ARD. The energy binding of ART was also smaller than that of ARD, -264 $\mathrm{kcal} / \mathrm{mol}$ compared to $-249 \mathrm{kcal} / \mathrm{mol}$. This study indicated that ART is more potential in the down-regulating mechanism of androgen signaling.
\end{abstract}

Keywords: androgen; diosgenin; in silico; phyto contraception; tigogenin

\section{INTRODUCTION}

The problem of developing country such as Indonesia, China, and India is population surge [1]. This is related to the feasibility of living arrangements, namely health, education, residence, and nutrition. Birth rate control is a global issue that is being addressed [2]. Government regulations regarding contraception and fertility management form an important component of reproductive balances [3]. The concept of family planning has been promoted with several methods applied to women such as IUD and birth control pills [4]. However, the serious side effects of the steroid synthesis contained in the drug make some people reluctant to use it.

The reluctance of the community to use contraceptive drugs is one of the causes of the implementation of programs that have not been maximized. Based on other perspectives, woman receives a lot of side effects from the use of contraceptive drugs such as fat, the emergence of zits, changing of menstrual cycles, and other effects [5]. Contraception can basically be applied to men, like vasectomy. But it can be worried that it may cause of the edge effect to decrease sex performance in men [6]. The use of phytocontraception was carried out in Sumatra as an alternative contraception
[7]. It is necessary to develop pytocontraception as a substitute for synthetic drugs and can be applied in men. Some researchers have tried to explore the benefits and efficacy of plants from the genus Costus which is known to have a role in the management of progesterone hormone expression [8]. It indicates that Costus specious can be used as pyto contraception for men. Devi et al. (2010) carried out a study to find out the effects caused by the administration of Costus picatus in female rats.They showed that there was a significant influence on fertility [7].

Many in vitro studies were carried out using diosgenin compounds, although there are still many other active compounds, one of which is tigogenin. Previous research has not found a difference and the optimal performance of diosgenin and tigogenin compounds to understand how Costus specious influences male fertility. Therefore, the study and analysis of the potential of phyto contraception from tigogenin by in sillico study is needed to support information about phyto contraception.

\section{METHODS}

\section{Protein and Ligands Preparation}

The Androgen Receptor (AR) (PDB ID:1A28) was downloaded from www.rcsb.org/pdb/. Diosgenin 
(CID: 119245) and tigogenin (CID: 99516) ligands were obtained from www.pubchem.ncbi.nlm.gih.gov with 3D-SDF. Their energy was optimized and converted to PDB format by PyRx 0.8. Ligands and water molecules in AR were removed by Discovery Studio Client 3.5.

\section{Docking and Visualization}

Docking among ligands and protein was done by Hex 8.0.0. We established two docking combinations. They were AR + diosgenin (as control) and AR + tigogenin. Furthermore the interactions were visualized by Discovery Studio Client 3.5.
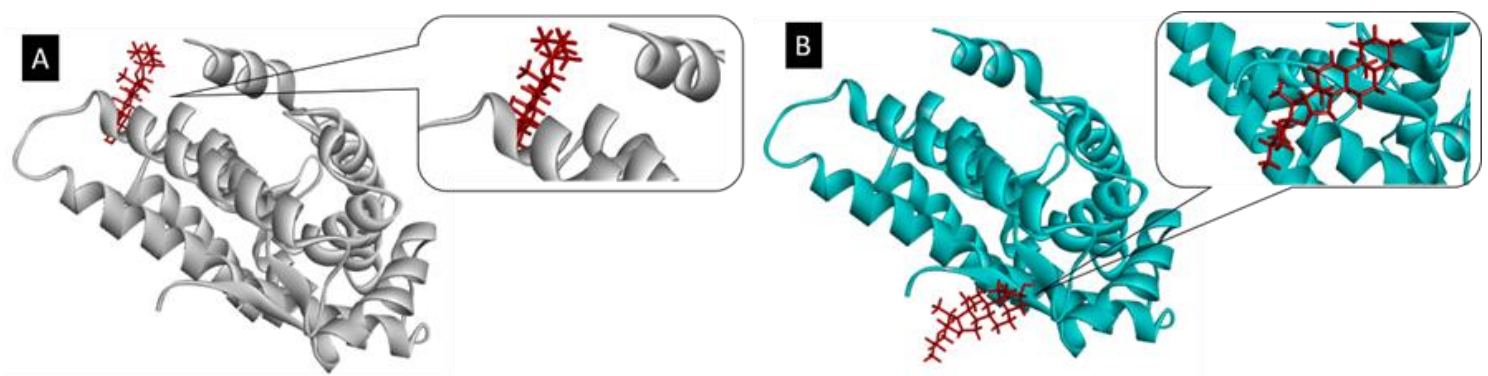

Figure 1. Site of interaction: A) Androgen Receptor+Diosgenin (ARD); B) Androgen Receptor+Tigogenin (ART)
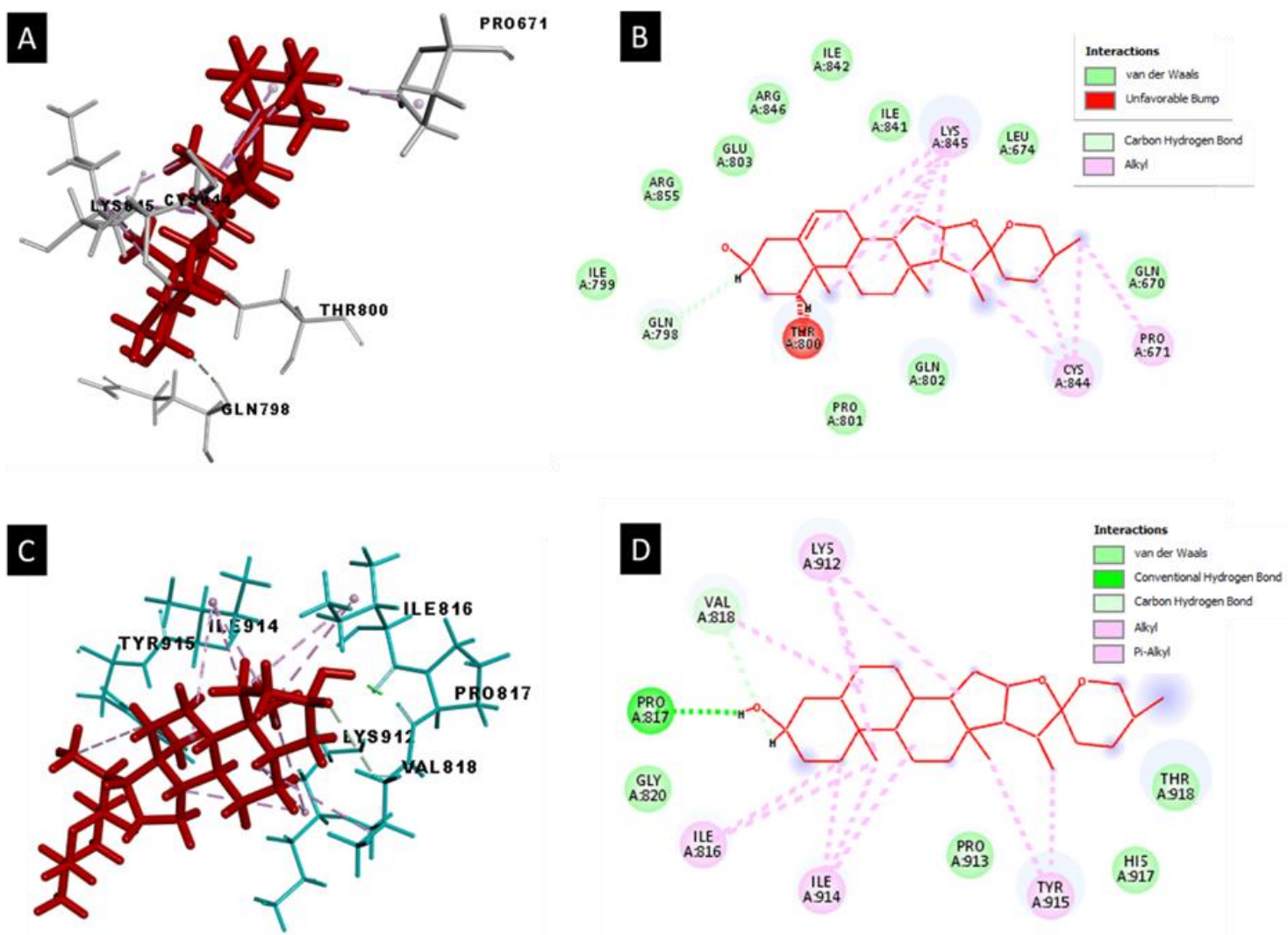

Figure 2. Protein-ligand interaction: a) 3D structure of ARD; b) 2D structure of ARD; c) 3D structure of ART; D) 2D structure of ART

\section{RESULTS AND DISCUSSIONS}

The docking results showed that the interaction of ARD had a different position from ART (Figure 1). The amino acid residues 798 to 844 were involved in the ARD interaction, while in ART interaction there were residues 817 to 915 . However, almost all of the residues were in the ligand binding domain, between 669-919 [9]. The ligand binding domain (LBD) is a domain that is responsible for binding hormones so that it can influence the formation of heat-shock protein complexes, activation and repression of transcription. If there is a ligand that binds to LBD, there will be a conformational change and gene expression in hormone proteins or receptors [10].

The interaction of ART established hydrogen bonds among ligands with PRO817 and VAL818, while diosgenin was only at GLN378 (Table 1 and 2). Hydrogen bonds have a high affinity for electrons which causes two different atoms or molecules to bind together [11]. So the more that interacts with the bond, it will easier to bond. The ART had 5 van der Waals bonds, while the interaction of ARD had 11 (Figure $2 \mathrm{~b}$ and $2 \mathrm{~d}$ ). 
Table 1. The interaction of AR with Diosgenin

\begin{tabular}{|c|c|c|c|c|c|c|}
\hline Name & $\begin{array}{l}\text { Distance } \\
\text { (§) }\end{array}$ & Category & Type & $\begin{array}{c}\text { From } \\
\text { Chemistry }\end{array}$ & $\begin{array}{c}\text { To } \\
\text { Chemistry }\end{array}$ & $\begin{array}{l}\text { Energy Binding } \\
\quad(\mathrm{kcal} / \mathrm{mol})\end{array}$ \\
\hline $\begin{array}{l}\text { :LIG1:H } \\
\text { - A:GLN798:O }\end{array}$ & 2.35316 & $\begin{array}{l}\text { Hydrogen } \\
\text { Bond }\end{array}$ & $\begin{array}{c}\text { Carbon } \\
\text { Hydrogen Bond }\end{array}$ & H-Donor & H-Acceptor & \\
\hline A:CYS844 - :LIG1 & 4.63438 & Hydrophobic & Alkyl & Alkyl & Alkyl & \\
\hline A:LYS845 - :LIG1 & 4.46208 & Hydrophobic & Alkyl & Alkyl & Alkyl & \\
\hline A:LYS845 - :LIG1 & 4.60698 & Hydrophobic & Alkyl & Alkyl & Alkyl & \\
\hline :LIG1:C - A:CYS844 & 5.11348 & Hydrophobic & Alkyl & Alkyl & Alkyl & -249 \\
\hline :LIG1:C - A:LYS845 & 3.90439 & Hydrophobic & Alkyl & Alkyl & Alkyl & \\
\hline :LIG1:C - A:LYS845 & 3.61078 & Hydrophobic & Alkyl & Alkyl & Alkyl & \\
\hline :LIG1:C - A:LYS845 & 4.50872 & Hydrophobic & Alkyl & Alkyl & Alkyl & \\
\hline :LIG1:C - A:PRO671 & 3.73231 & Hydrophobic & Alkyl & Alkyl & Alkyl & \\
\hline :LIG1:C - A:CYS844 & 4.50411 & Hydrophobic & Alkyl & Alkyl & Alkyl & \\
\hline
\end{tabular}

Table 2. The interaction of AR with Tigogenin

\begin{tabular}{|c|c|c|c|c|c|c|}
\hline Name & 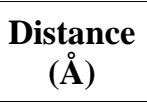 & Category & Type & $\begin{array}{c}\text { From } \\
\text { Chemistry }\end{array}$ & $\begin{array}{c}\text { To } \\
\text { Chemistry }\end{array}$ & $\begin{array}{c}\text { Energy Binding } \\
\text { (kcal/mol) }\end{array}$ \\
\hline $\begin{array}{l}\text { :LIG1:H - } \\
\text { A:PRO817:O }\end{array}$ & 1.99428 & $\begin{array}{l}\text { Hydrogen } \\
\text { Bond }\end{array}$ & $\begin{array}{l}\text { Conventional } \\
\text { Hydrogen Bond }\end{array}$ & H-Donor & H-Acceptor & \multirow{13}{*}{-264} \\
\hline $\begin{array}{l}\text { :LIG1:H - } \\
\text { A:VAL818:O }\end{array}$ & 3.01743 & $\begin{array}{l}\text { Hydrogen } \\
\text { Bond }\end{array}$ & $\begin{array}{c}\text { Carbon } \\
\text { Hydrogen Bond }\end{array}$ & H-Donor & H-Acceptor & \\
\hline A:VAL818 - :LIG1 & 4.69027 & Hydrophobic & Alkyl & Alkyl & Alkyl & \\
\hline A:LYS912 - :LIG1 & 5.34944 & Hydrophobic & Alkyl & Alkyl & Alkyl & \\
\hline A:LYS912 - :LIG1 & 4.68678 & Hydrophobic & Alkyl & Alkyl & Alkyl & \\
\hline A:ILE914 - :LIG1 & 5.23072 & Hydrophobic & Alkyl & Alkyl & Alkyl & \\
\hline :LIG1:C - A:ILE816 & 5.46097 & Hydrophobic & Alkyl & Alkyl & Alkyl & \\
\hline :LIG1:C - A:ILE914 & 4.91282 & Hydrophobic & Alkyl & Alkyl & Alkyl & \\
\hline :LIG1:C - A:ILE816 & 4.97249 & Hydrophobic & Alkyl & Alkyl & Alkyl & \\
\hline :LIG1:C - A:LYS912 & 5.13021 & Hydrophobic & Alkyl & Alkyl & Alkyl & \\
\hline :LIG1:C - A:ILE914 & 4.57687 & Hydrophobic & Alkyl & Alkyl & Alkyl & \\
\hline A:TYR915 - :LIG1:C & 4.90223 & Hydrophobic & Pi-Alkyl & Pi-Orbitals & Alkyl & \\
\hline A:TYR915 - :LIG1:C & 5.43787 & Hydrophobic & Pi-Alkyl & Pi-Orbitals & Alkyl & \\
\hline
\end{tabular}

Theories and experiments show that van der Waals forces help in improving the structure of proteins by stabilizing their bonds [12]. However, it could not be assured that ARD was more stable due to its high Van der Waals bonds. ARD had unfavorable bumps (Figure 2b). Some studies suggest that unfavorable bump causes the bond to become unstable. Hydrophobic bonds are known to be one of the more important factors involved in stabilizing folding configurations in native proteins [13]. The overall interactions of ART had more hydrophobic bonds than the interactions of ARD (Table 1 and 2).LYS845 in tigogenin compounds are amino acids that have more alkyl groups than ILE914 in diosgenin compounds so that there are differences in the conformation of the two compounds which will affect the specificity of drug compounds against receptors [14]. The mechanism for inhibiting androgen can be explained by investigating the mechanism between tigogenin and diosgenin with Androgen Receptor (AR). This study observed that tigogenin had lower binding energy than diosgenin (Table 1 and 2). This showed a more stable interaction between AR and tigogenin than in ARdiosgenin complex. If androgens are blocked, the androgens and AR do not act to form spermatogenesis. When initiated with a complementary ligand, the androgen receptor (in men) will bind, so no interaction with the hormone testosterone and DHT is formed. This results in no 
occurrence of RNA polymerase II transcripts, TBP, TAF's, and GTPs not occurring [9]. Therefore, the existence of interactions between androgens and tigogenin may result in a decrease in sperm production in men.

\section{CONCLUSION}

The data were supported with some parameters, such as the interaction of androgen recepor with tigogenin had a lower energy than with diosgenin, tigogenin had a strategic position and a stable amino acid residues binding. Our study suggests that tigogenin has a potency for phyto contracepcy due to its ability to bind the ligan binding domain of androgen receptors. Therefore, the productivity of sperm may be decreased.

\section{ACKNOWLEDGEMENTS}

We would like to thank to the team of Bioinformatics for leading and providing the facilities.

\section{REFERENCES}

1. Purba, A.Z.U, Trips and Developing Countries, IJIL 2004, Vol.1 (2).

2. Solo, J.L.M. \& Wohlfart, D., Repositoning Faily
Planning Zambia Case-study Read, 2005.

3. Marni, Pelayanan KB, 2016, Pustaka Pelajar, Yogyakarta.

4. Bawing, P., R.S. Padmawati., S.A. Willopo. BKM Journal Community Medicine and Public Health. 2017, Vol.33, 516-622.

5. Sari, I.P., S. Rahayu., D.M. Rixal. Infusa Daun Pacing Costus speciosus (Koen.) sebagai Penghambat Jumlah dan Kualitas Spermatozoa pada Mencit Jantan BALB/C. 2012.

6. Faris, A.D. \& S.Indarjo, UJPH, 2015, Vol. 4, 8693.

7. Devi V, Urooj A., Indian Journal of Natural Products and Resources, 2010, Vol. 1 (1), 116118.

8. Hasbi, H. \& Gustina, S., WARTAZOA, 2018, 28 (1).

9. Akmal, M., Veterina Medika, 2017, 10 (1).

10. Panigrahi SK, Desiraju GR., Proteins, 2007, 67(1), 128-141.

11. Bowie J. U., Current opinion in structural biology, 2010, 21(1), 42-49.

12. Finkelstein AV, Lobanov MY, Dovidchenko NV, Bogatyreva N.S., J Bioinform Comput Biol, 2008, 6(4), 693-707.

13. Müller, D. J., Wu, N., \& Palczewski, K., Pharmacological reviews, 2008, 60 (1), 43-78.

14. Ekowati, J \& Nuzul, N. Diyah., Berkala Ilmiah Kimia Farmasi, 2013, Vol.2 No. 1. 